\title{
Lexico-Semantic Manipulative Devices in the 2016 U.S. Presidential Debates
}

\author{
By \\ Wael Mohamed Kotb Khedr \\ PhD Degree- English Department, Faculty of Arts, Suez University
}

\section{Under the supervision of}

\author{
Dr. Shaker Rizk Taky El-Din \\ Professor of Linguistics \\ Faculty of Arts- Suez University
}

Dr. Shaymaa Taher Sallam Assistant professor of Linguistics

Faculty of Arts- Suez University

\begin{abstract}
This study examines some of the lexico-semantic manipulative devices in the 2016 U.S. presidential debates between Hillary Clinton and Donald Trump. The lexico-semantic manipulative devices included in this study are conceptual metaphors, equivocations, and emotive language. The study concluded that Donald Trump used the three lexico-semantic manipulative devices more than his opponent. It also indicated that while emotive language was the most dominant used device, equivocations are the least used. It also showed that of the twenty different categories of conceptual metaphors, object metaphors were the most used category. The study also concluded that the different categories of conceptual metaphors help in both making the abstract ideas clearer and creating the image of the two candidates' political persona. The study clarified the important role played by the emotive language in evoking the audiences' emotions and feelings. The study also concluded that manipulation can easily finds its way through the skillful use of the four categories of equivocations (sender, receiver, context, and content).
\end{abstract}

Keywords: lexico-semantic devices, linguistic manipulation, 2016 U.S. presidential debates, political discourse, 2016 televised debates. 


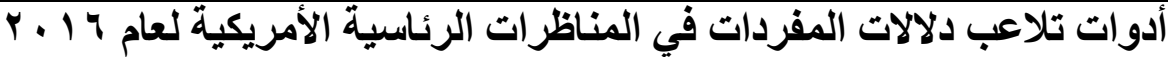

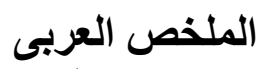

تهدف هذة الدر اسة إلى در اسة بعض من أدوات تلاعب دلالات المفردات في المناظر ات الرئاسية

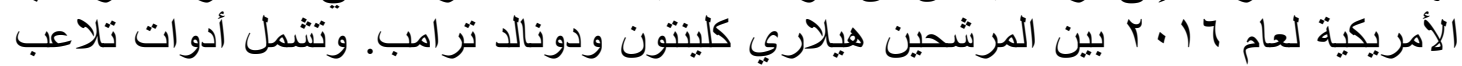

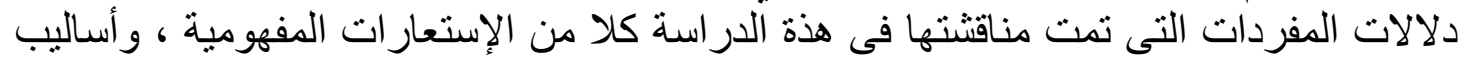

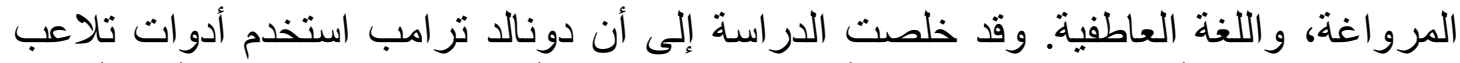

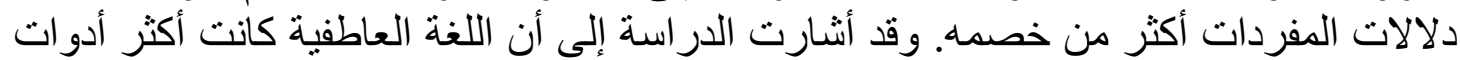

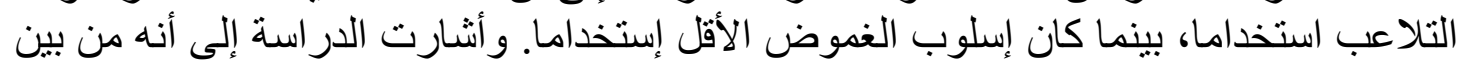

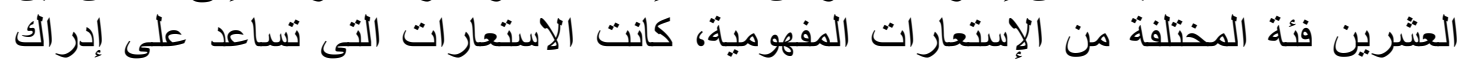

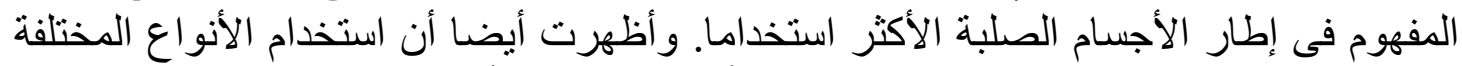

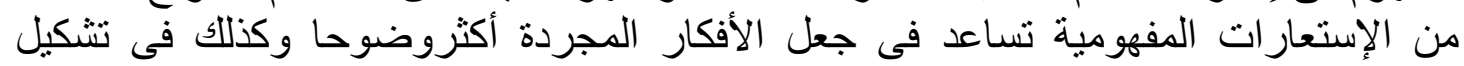

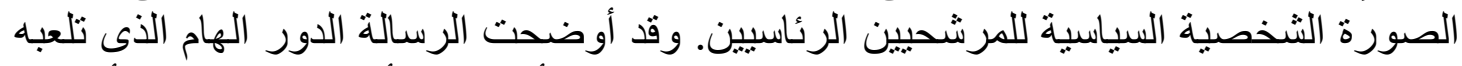

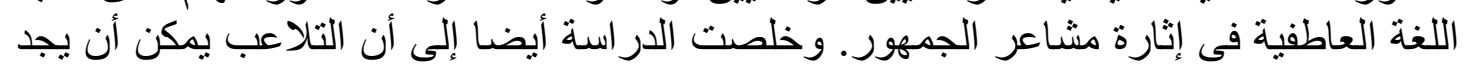

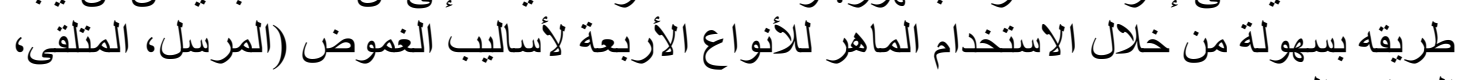
السياق، المحتوى).

الكلمات المفتاحية: أدوات المات دلالات المفردات، التلاعب اللغوى، المناظرات الرئاسية الأمريكية

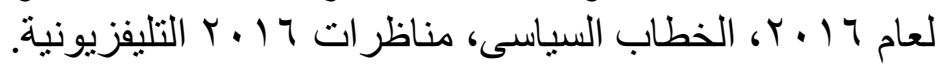




\section{Wael Mohamed Kotb Khedr}

\section{1-Introduction}

Language has many uses. Besides the main purpose of the language as a means of communication, every person uses language to achieve specific goals with their communication. Language is the tool that religious preachers and community leaders use to gain a public following. Commonly utilized in everyday interpersonal communication, manipulation is one of the many different uses of language. Speakers usually benefit from this linguistic act when trying to mislead or deceive their listeners in order to achieve their purposes. Manipulation is usually achieved when listeners are unable to realize the speakers' hidden intention behind what is being said (Asya, 2013). Taking into account the effective roles of manipulative language devices in oral discourse, speakers use these devices for a broad range of purposes.

In their attempts to manipulate their listeners, speakers use a variety of linguistic means, despite the negative impact of using subterfuge and vilification. Some speakers tend to attack their listeners to achieve their goals. Attacking individuals in positions of power is popular among politicians, especially those who aspire to run for office. Shifting blame, avoiding responsibility, and distracting from uncomfortable truths are some of the main reasons why speakers attempt to manipulate their listeners.

This study aims at studying how Hillary Clinton and Donald Trump used the different lexico-semantic manipulative devices to direct their audiences to accept their ideas and argument. It shows both the most frequently used and the least used lexico-semantic manipulative devices.

\section{Statement of the Problem}

Due to the 2008 world economic crisis, the whole world paid much attention to the 2016 U.S. presidential election. The outcome of this election affected not only the United States, but also all the world due to globalization and derivational economic independence.

With the help of the interviewers, the two presidential candidates discussed many controversial issues and topics. One of these topics is dealing with Muslims and allowing them to enter the United States. Before the 2016 elections, Trump called for a total and a complete shutdown of Muslims' entering the country (Duffy, 2018; Musolff, 2019). During the Democratic Convention, he attacked the Gold Star Khan family (an army Captain who was killed in Iraq in 2004), and prevented Ghazala Khan from speaking due to her Islamic faith (Duffy, 2018; Musolff, 2019). He also accused American Muslims of supporting terrorism (Musolff, 2019). He also attacked, but not to the same degree, 
other minorities like Latinos and African Americans. Trump attacked women to such an extent that both his wife and his daughter publicly defended him for his unprofessional behavior toward women. He also presented his economic plans which were supposed to create only 3.5 million jobs. His opponent's plans were estimated to offer 10 million job opportunities. The above-mentioned issues were completely presented in the three 2016 presidential debates. There are two other reasons for studying the use of manipulative language structures in the three 2016 presidential debates.

The 2016 election provides the prime opportunity to study the different manipulative devices the two candidates used in the three debates under analysis, as they attempt to garner perceived social and political capital. The study considers potential manipulation through discussing the different verbal lexico-semantic manipulative devices that the two candidates use in their three 2016 presidential debates. The other reason for discussing manipulative language structures in these debates is that verbal lexico-semantic manipulative devices have not been discussed in these three debates yet.

\section{Objectives of the Study}

This study aims at:

1- Examining how the two presidential candidates, Hillary Clinton, and Donald Trump, used some lexico-semantic manipulative devices in order to gain a huge public following, control their audiences, and shape their minds and opinions.

2- Discussing how the choice of the emotive language and metaphors can generate and arouse emotions on the part of the audiences.

3- Analyzing the use of different categories of metaphors, equivocations, and emotive language in the presidential debates.

4- Defining the crucial role played by equivocation techniques in boosting manipulation in political discourse.

\section{Research Questions}

This study aims at answering the following questions:

1- What are the different verbal lexico-semantic manipulative devices used by the presidential candidates in the debates under consideration?

2- What are the most and least frequently used lexico-semantic manipulative devices?

3- How is verbal manipulation considered as an important factor in winning the presidential election? 


\section{Wael Mohamed Kotb Khedr}

\section{Study Hypotheses}

This Study is based on the following assumptions:

1. Manipulation can be achieved verbally and psychologically.

2. Manipulation plays an important role in winning presidential elections.

3. Manipulation implies persuasion with the aim to control the person on the other side of the conversation into doing something.

4. Each candidate employed a different way of talking because each one projected a different personality in an effort to persuade the audience in the presidential debates.

5. The pragmatic nature of manipulation is revealed by studying it through its relation to various pragmatic theories.

\section{Review of Literature}

Many researchers have studied manipulation in terms of political discourse, legal discourse, and news reporting. Some researchers have focused on the discourse analysis approach in their analysis of the 2016 U.S. presidential debates. The following review introduces some of the studies that tackle both linguistic manipulation and the 2016 U.S. presidential debates.

In her 2018 study, The 2016 U.S. Presidential Debates: A Discourse Analysis Approach, Lucía Palacios presented seven linguistic features in her analysis of the three presidential debates. These seven markers are personal pronouns, fillers, conceptual metaphors, equivocations, interruptions, contrastive pairs, and the three-part lists. Palacios concluded that both Trump and Clinton used conceptual metaphors and fillers with almost the same frequency in political exchanges (Palacios, 2018). Hillary Clinton preferred to use the personal pronouns in order to defend her viewpoint by avoiding assuming the whole responsibility (Palacios, 2018). Palacios also concluded that Trump used many personal pronouns in order to directly attack his opponent. Trump also made use of many three-part lists, interruptions, contrastive pairs, and equivocations in the three presidential debates (Palacios, 2018).

The current study is different from Palacios' study in that it concentrates on the intention behind the two candidates using each of these lexico-semantic manipulative devices. Palacios' study was meant "to analyze the style adopted by the two candidates through the examination of seven particular features used in the context of a formal political interview" (Palacios, 2018, p.4). When studying conceptual metaphors and personal pronouns, the present study concentrates on how these markers help in generating and arousing emotions on the part of the audiences, and therefore, achieving the two candidates' goals. While 
Palacios' study concentrated mainly on persuasion, the current study focuses on manipulation. Unlike this study which concentrates on all the different types of personal pronouns (18 pronouns), Palacios refers only to five pronouns (She does not even exclude the exclusive "we"). She does not exclude the pronouns that the two candidates use when quoting others. She also does not present specific examples to show how and why the two candidates use the different markers. Instead, she analyzes the debates in general.

In a study entitled Analyzing the (Ab)use of Language in Politics: The Case of

Donald Trump, Ana Alonso Curbelo (2017) studied fifteen speeches during Donald Trump's 2016 U.S. presidential election campaign. These speeches were given between June 16th and November 8th of the year 2016. The main purpose of this research paper is to show how Trump used both the political discourse and language to attract different audiences. Two different types of analyses are presented in this paper: analysis of similarities and descending hierarchical analysis. Curbelo states that "Donald Trump's language and political discourse were instrumental in his pursuit of symbolic power and legitimization reflected in his electoral success in 12 out of the 15 states analyzed, three of which were historically Democratic states" (Curbelo, 2017, p. 19). She also stresses on the fact that language cannot be studied in isolation. The contextuality and intertextuality of words should be taken into account (Curbelo, 2017).

In a study entitled The Use of Metaphors in Hillary Clinton's Presidential Debate, Fuji Ruhita Arfiani (2017) concluded that ontological metaphors are the dominant type of conceptual metaphors used by Hillary Clinton in the three 2016 presidential debates. The study also concludes that inexpressibility hypothesis, compactness hypothesis, and vividness hypothesis are the three hypotheses of communicative functions of metaphor given by Fainsilber and Ortony (1989) in Gibbs (1994).

When discussing the change of the use of conceptual metaphors in depicting the idea of immigration over the past century, Smith (2019) concludes that Donald Trump's rhetorical language and his use of conceptual metaphors had a lot of similarities with the 1920s antiimmigration side's arguments. The study indicates that Trump has seen immigrants as the reason for all the economic and security problems facing the country (Smith, 2019).

In his 2017 study Language function used by Hillary Clinton in the presidential debates of United States of America in 2016, Eka Sartika 


\section{Wael Mohamed Kotb Khedr}

(2017) discusses the different language functions used by Hillary Clinton in the 2016 presidential debates. He announces that six functions are present in these debates. These functions are: referential, conative, emotive, poetic, pathetic, and metalinguistic. He concluded that there are 17 emotive functions used by Hillary Clinton in these three debates. The main aim behind using the emotive function is to convey her feelings and emotions to her audiences (Sartika, 2017). The present study is different from Sartika's study in the way that it presents the frequency occurrences of all the emotive words used in the debates and the reasons behind using such emotive expressions.

Feldman, Kinoshita, and Bull (2015) studied the crucial role played by equivocation in Japanese televised interviews. The study concluded that both local and national politicians tend to significantly employ equivocation rather than nonpoliticians. It also showed that politicians who are in power tend to equivocate more often than who represent opposition movements and parties. Politicians who are in power are "more vulnerable to communicative conflicts that will lead them to equivocate when replying to questions" (Feldman, Kinoshita, \& Bull, 2015, p. 86).

As mentioned earlier in this section, manipulation has been studied in terms of other genres like legal genre. In a research paper entitled Rhetoric and Psychopathy: Linguistic Manipulation and Deceit in the Final Interview of Ted Bundy, Rebcca Smithson (2013) analyzed the last interview with Ted Bundy, an American rapist and serial killer who eventually confessed to being responsible for the deaths of at least thirty women(Smithson, 2013). Smithson concluded that some of Aristotle's modes of persuasion like ethos and pathos are connected with potentially manipulative aspects of Bundy's language, such as the use of the plural first pronoun, the conceptual metaphors, and the application of modal auxiliaries (Smithson, 2013). Through the use of the above-mentioned manipulative devices, Bundy tried to persuade both the audience and the interviewer that he was not a criminal. Instead, as he claimed, he was a victim of sexual violence.

From the above-mentioned previous research studies, we can conclude that there is no research that tackled the influence of the lexicosemantic manipulative devices in shaping the minds of listeners and allow them to either accept an idea or change their mind regarding another. There seems to be a dire need for some new studies to discuss such influence. Therefore, the present study is intended to investigate how the two presidential candidates skillfully employ the different lexico-semantic 
manipulative devices to shape their audiences' minds. This is greatly noticed in how more than one device can be used at the same time.

\section{Methodology}

The study quantitatively and qualitatively analyzes the three 2016 U.S. presidential debates in the light of three lexico-semantic manipulative devices. These devices are the conceptual metaphor theory, the equivocation technique, and the emotive language. The study presents the three types of conceptual metaphors as introduced by Lakoff and Johnson in their 1990 famous book Metaphors We Live By. These three types are the structural metaphors, the ontological metaphor, and the orientational metaphors. It also shows the twenty different categories of conceptual metaphors (by source domain).The study also explains how Bavelas et al.'s equivocation taxonomy was used by the two candidates in their attempt to manipulate their audiences. It also explores the powerful role played by the emotive language in attracting the attention of the audiences.

\subsection{Data}

The data of the study includes the three U.S. presidential debates that were held in 2016. The two candidates were the Republican candidate Donald Trump and the Democratic candidate Hillary Clinton. The first debate was held on September 26, 2016, at New York's Hofstra University. This debate was chaired by Lester Holt of National Broadcasting Company (NBC). It lasted for ninety-five minutes. Donald Trump spoke for forty-five minutes and three seconds, while Hillary Clinton spoke for forty-one minutes and fifty seconds. The interviewer asked questions which focused on nuclear weapons, economy improvement, cyber attacks, and race. An estimated 84 million people watched this debate (The Nielsen Company, 2008).

The second debate was held on October 9, 2016, at Washington University. The debate was moderated by Anderson Cooper of Cable News Network (CNN) and Martha Raddatz of American Broadcasting Company (ABC). The debate lasted for ninety minutes. Donald Trump spoke for forty minutes and ten seconds, while Hillary Clinton spoke for thirty- nine minutes and five seconds. Unlike the other two debates, the audience and people through the different social networking websites asked the questions. The questions revolved around the war in Syria, Islamophobia, the economy, and healthcare. An estimated 66 million people viewed this debate (The Nielsen Company, 2008). 


\section{Wael Mohamed Kotb Khedr}

The third debate took place on October 19, 2016, at the University of Nevada, in Las Vegas. The debate was chaired by Chris Wallace of Fox News. It lasted for ninety-three minutes. Trump spoke for thirty -five minutes and forty-one seconds, while Clinton spoke for forty- one minutes and forty -six seconds. The final debate discussed the topics of immigration, abortion, the war in Syria, economy, and cyber-attack. Approximately 71.6 million people saw this televised debate (The Nielsen Company, 2008).

The data of this research were collected from two different websites with different form of data. The first one was the video of the three of the United States of America presidential debate 2016 downloaded from youtube.com. The username of the channel of the video is NBC News, this YouTube channel belongs to NBS TV. The second one was the transcript of those three presidential debates, downloaded from presidential website called The American Presidency Project

\section{Theoretical Background}

This section aims at presenting a brief account on the three lexicosemantic manipulative devices known as conceptual metaphors, equivocations, and emotive language.

\subsection{Conceptual Metaphors}

Politicians tend to make use of metaphors in their attempt to achieve manipulation. A metaphor is "a figure of speech in which a word or phrase literally denoting one kind of object or idea is used in place of another to suggest a likeness or analogy between them" (Merriam Webster Dictionary, 2016). A metaphor "serves multiple functions in persuasive communication and the effect of metaphor on persuasion is potentially mediated by multiple psychological process mechanisms" (Ottati \& Renstrom, 2010, p. 1).

Linguists have studied metaphors according to various linguistic theories, including the traditional approach, conceptual metaphors, and the relevance theory. Seeing metaphors as a type of language decoration is the idea adopted by the traditional approach of critical discourse analysis. Metaphors, according to this approach, are used only in the fields of rhetoric and stylistics. They are extensively used in poetry and prose to add beauty. Metaphors formerly had only one form or formula which is " $\mathrm{X}$ " is " $Y$ ". Unlike the traditional approach, which confined the use of metaphor only to poetry, the conceptual metaphor theory sees metaphor as a part of our everyday communication.

One foundational theory by prominent American linguists Lakoff and Johnson is known as the conceptual metaphor theory (CMT). They 
claim that metaphors are not restricted to certain genres and fields. Metaphors are pervasive in every form of language (Lakoff \& Johnson, 1990). For each metaphor, two domains must exist: the source domain and the target domain. Source domain is the conceptual domain from which we draw metaphorical expressions to understand another conceptual domain. The target domain is the conceptual domain that is understood this way (Lakoff \& Johnson, 1990). In the example "LOVE IS A JOURNEY", the word "love" is the target domain, while the use of the word "journey" represents the source domain (Lakoff \& Johnson, 1990; Lakoff, 2001; Knowles \& Moon, 2006). In addition to articulating the difference between source and target domains, the theory presents three main kinds of conceptual metaphors.

Lakoff and Johnson present three types of conceptual metaphors: structural, orientational, and ontological. Structural conceptual metaphor is the first kind in which one abstract concept is represented in terms of another concrete concept. "ARGUMENT IS WAR" is an example of this kind of conceptual metaphors, which is found in great numbers. A large number of English sentences can express this metaphor such as "I demolished his argument", "he defended his argument", and "He shot down all of my arguments" (Lakoff \& Johnson, 1980, p.48). In addition to the structural conceptual metaphor, there is another type of conceptual metaphor that deals with spatial relationships.

The second type of conceptual metaphor is the orientational conceptual metaphor. This kind of conceptual metaphor involves spatial relationships such as up-down, in-out, and on-off (Lakoff \& Johnson, 1980; Kovecses, 2005). The orientational conceptual metaphor "HAPPY IS UP, "SAD IS DOWN" is presented by Lakoff and Johnson in their book Metaphors We Live By. This metaphor can also be shown in other everyday expressions like "I am feeling up", "I am feeling down", "My spirits rose", and "My spirits sank". Orientational metaphors are connected with our physical experiences (Lakoff \& Johnson, 1980). Not only does conceptual metaphor theory contain structural metaphor and orientational metaphor, but also it involves ontological conceptual metaphors.

The ontological conceptual metaphor is the last type of metaphors that Lakoff and Johnson introduce in their classifications of the conceptual metaphor theory. In this type of metaphor, ideas and events are seen as intangible substances (Lakoff \& Johnson, 1980). Ontological metaphors are natural and persuasive in thought (Lakoff \& Johnson, 1980). "INFLATION IS AN ENTITY" is an example of ontological metaphors. It can be expressed in other expressions like "Inflation makes 


\section{Wael Mohamed Kotb Khedr}

me sick", "We need to combat inflation", "Inflation is backing us into a corner", and "Buying land is the best way of dealing with inflation" (Lakoff \& Johnson, 1980). According to Lakoff and Johnson, "viewing inflation as an entity allows us to see it as a cause, identify a particular aspect of it and have certain feelings in accordance with it" (Lakoff \& Johnson, 2003). Ontological metaphors can be presented in personification, hyperbole, metonymy, simile, and idiomatic expressions. In addition to the traditional approach and the conceptual metaphor theory, metaphors are also central to another theory that pays special attention to the intention of the speakers.

Metaphors have also been studied in terms of another theory called the relevance theory (RT) introduced by Sperber and Wilson in 1986. Metaphor "is not a theoretically important notion in the study of verbal communication....There is no mechanism specific to metaphors, and no interesting generalization that applies only to them" (Sperber \& Willson, 2008 , p. 84). They claim that communication is a continuum from literal to non-literal talk, and metaphor is placed towards the non-literal end (Sperber \& Willson, 2008).

\subsection{Semantic Equivocations}

Equivocation is defined as "the use of equivocal or ambiguous expressions, especially in order to mislead or hedge; prevarication" (Dictionary.com, 2015). Equivocation is a technique that presidential candidates usually use to hedge messages or mislead listeners. Presidential candidates tend to extensively use this technique when they do not have the sufficient information to answer a question. According to Bavelas, Black, Bryson and Mullet (1988), "equivocal communication is not desirable, but from the point of view of politician-interviewer interaction, it is at present inevitable" (p.144).

There are many different perspectives of using the equivocation techniques. Trying to avoid tackling and addressing the difficult situations was the early aspect of equivocations (Lewin, 1939). Equivocation is a technique that politicians use to avoid answering difficult questions (Vrij, 2008). While equivocation is a good technique that interviewees use to escape unpleasant questions, it has some disadvantages that make communication unclear due to the potentially intentional ambiguity in the evasive responses.

The use of the equivocation technique can cause many undesirable traits such as lack of clarity, ambiguity, and possible intentional deception. Using the equivocation technique is connected with the lack of clarity when speakers do not directly answer the questions posed to them (Bavelas et al., 1988). A speaker's main aim of using such lack of clarity 
is to escape from the negative consequences if they use clear facts and answers. Equivocation is also connected with dishonesty when speakers avoid telling the truth, or when they tell half- truths. It can also be associated with ambiguity when speakers use the opinions of others.

There are four main elements for any successful communication. These key elements are sender, receiver, content, and context (Bavelas et al., 1990, Haley, 1959). If one or more of these four elements are broken, equivocation easily finds its way. So equivocation is the "departure from essentials of clear communication" (Bavelas et al., 1990, Haley, 1959). Speakers tend to equivocate in avoidance- avoidance conflicts where all the answers to a question have negative consequences, but the speaker should give an answer (Bavelas et al., 1990). Since all the participants and the audience wait for an answer, speakers are forced to use equivocations to mitigate the negative and undesirable consequences of such an answer. Being able to decide when to use the equivocation technique, speakers can use one of the three groups of equivocations.

Studying the importance of equivocation in political debates, Bull claims that equivocations can fall into three groups: replies, intermediate replies, and non-replies (Bull 2012; Bull, 2003). By replies he means the information given by the candidate in response to the interviewer's question. Non-replies are the opposite of replies; the politician does not provide the information as requested by the interviewer. Intermediate replies are something between replies and non-replies. Candidates use these non-replies because "the politician cannot be said to have given a full reply to the question, but nor can he or she be said not to have given a full reply at all" (Bull, 2003, p. 110).

There are different forms of equivocation that interlocutors use when having an interview or holding a debate. Some interviewees, when asked difficult or sharp questions, tend to attack the interviewers in order to force them to ask new questions (Bull \& Mayer,1993; Bull 2008). Some interviewees use what is called the negative answers, in which they would state what would not happen instead of stating what would happen. There are some other equivocation forms such as ignoring the question, acknowledging the questions without answering them, giving insufficient answers, repeating previous answers, refusing to answer, and asking questions about the question (Bull \& Meyer, 1993; Bull, 2012).

\subsection{Emotive Language}

Another lexico-semantic manipulative device used by speakers in general, and politicians in particular is the use of emotive language or emotionally loaded-words. Emotive language means the speakers' or the writers' use of words and phrases that stir, evoke, and generate the 


\section{Wael Mohamed Kotb Khedr}

listeners' or readers' emotions and feelings (Wallace et al., 2012). Speakers tend to use emotive language when describing their feelings or reflecting a subjunctive attitude (Kazemifard et al., 2012). If the speakers use emotive language properly and effectively, it enables the audiences to react in a particular way. In order to enhance positive or negative emotional reactions, speakers tend to use the different forms of emotive language such as adjectives, adverbs, inclusive pronouns, some verbs, exclamations, or certain proper nouns (Kazemifard et al., 2012). Speakers employ emotive language to cause an intended effect on the audience.

The use of the emotive language is not confined to literature. Emotive language can easily be found in the different types of everyday interactions. Politicians use it as a technique when trying to persuade or manipulate their opponents and voters. Through the perfect use of the emotive language, speakers can easily achieve and reach what they desire. A good example of a public speaker using this technique effectively is Martin Luther King, Jr., who led the civil rights movement in the United States in the 1950s and 1960s (Mieder, 2010).

\section{Analysis}

The two presidential candidates employ the three verbal lexicosemantic manipulative devices in their attempt to manipulate their audiences as the following table shows:

Table 1. The occurrences of the three lexico-semantic manipulative devices

\begin{tabular}{|c|c|c|c|c|c|c|c|c|}
\hline \multirow{2}{*}{$\begin{array}{l}\text { Lexico- } \\
\text { semantic } \\
\text { manipulative } \\
\text { device }\end{array}$} & \multicolumn{3}{|c|}{ Hillary Clinton } & \multirow[b]{2}{*}{ Total } & \multicolumn{3}{|c|}{ Donald Trump } & \multirow[b]{2}{*}{ Total } \\
\hline & $\begin{array}{l}1^{\text {st }} \\
\text { Debate }\end{array}$ & $\begin{array}{l}2^{\text {nd }} \\
\text { Debate }\end{array}$ & $\begin{array}{l}3^{\text {rd }} \\
\text { Debate }\end{array}$ & & $\begin{array}{l}1^{\text {st }} \\
\text { Debate }\end{array}$ & $\begin{array}{l}2^{\text {nd }} \\
\text { Debate }\end{array}$ & $\begin{array}{l}3^{\text {rd }} \\
\text { Debate }\end{array}$ & \\
\hline $\begin{array}{l}\text { Conceptual } \\
\text { metaphor }\end{array}$ & 177 & 171 & 196 & 544 & 231 & 220 & 181 & 632 \\
\hline Equivocations & 44 & 21 & 35 & 100 & 68 & 41 & 39 & 148 \\
\hline $\begin{array}{l}\text { Emotive } \\
\text { language }\end{array}$ & 359 & 329 & 351 & 1039 & 522 & 424 & 478 & 1424 \\
\hline Grand Total & 580 & 521 & 582 & 1683 & 821 & 685 & 698 & 2204 \\
\hline
\end{tabular}

As table 1 shows, the two candidates employ the three verbal lexico-semantic manipulative devices (3887) times: (1683) times (43.2\%) by Hillary Clinton, and (2204) times $(56.8 \%)$ by Trump. The first debate, on the one hand, has the highest number of these devices (36\%), because the two candidates want to establish a solid ground before their audiences from the beginning. The second debate, on the other hand, has the lowest number of $(31 \%)$. Of the three lexico-semantic manipulative devices, emotive language is the most used device $(63.3 \%)$, while equivocations are the least used (6.3\%). The following section discusses in brief how 
the three lexico-semantic devices are quantitatively and qualitatively used by the three debates under analysis.

\subsection{Categories of Conceptual Metaphors (by source domain)}

Taking into account the profound effect of conceptual metaphors on the audiences, the two candidates pay much attention to many different categories of these conceptual metaphors. Clinton and Trump are found using person metaphors, object metaphors, motion metaphors, building metaphors, force metaphors, container and liquid metaphors, journey metaphors, physical suffering metaphors and others when presenting the different issues. The main aim behind using these varieties of metaphors is to give their audiences a powerful image of the topics they are discussing. The following table shows the occurrences of the different categories of the conceptual metaphors (by source domain) in the debates under analysis:

Table 2.Categories of Conceptual Metaphors (by source domain)

\begin{tabular}{|c|c|c|c|c|c|c|c|c|}
\hline \multirow[b]{2}{*}{ Metaphor } & \multicolumn{3}{|c|}{ Hillary Clinton } & \multirow[b]{2}{*}{ Total } & \multicolumn{3}{|c|}{ Donald Trump } & \multirow[b]{2}{*}{ Total } \\
\hline & \begin{tabular}{|l|}
$1^{\text {st }}$ \\
Debate \\
\end{tabular} & $\begin{array}{l}2^{\text {nd }} \\
\text { Debate }\end{array}$ & $\begin{array}{l}3^{\text {rd }} \\
\text { Debate }\end{array}$ & & $\begin{array}{l}1^{\text {st }} \\
\text { Debate }\end{array}$ & $\begin{array}{l}2^{\text {nd }} \\
\text { Debate }\end{array}$ & $\begin{array}{l}3^{\text {rd }} \\
\text { Debate }\end{array}$ & \\
\hline Object & 45 & 59 & 56 & 160 & 71 & 72 & 55 & 198 \\
\hline Person & 33 & 30 & 38 & 101 & 53 & 33 & 33 & 119 \\
\hline Spatial & 27 & 36 & 40 & 103 & 29 & 38 & 21 & 88 \\
\hline Competition & 17 & 7 & 14 & 38 & 23 & 16 & 17 & 56 \\
\hline Building & 11 & 7 & 6 & 24 & 5 & 8 & 16 & 29 \\
\hline Force & 8 & 3 & 3 & 14 & 5 & 20 & 10 & 35 \\
\hline Plant & 7 & - & 9 & 16 & 4 & 4 & 9 & 17 \\
\hline Container & 4 & 7 & 11 & 22 & 13 & 11 & 7 & 31 \\
\hline Liquid & - & - & 2 & 2 & 1 & 3 & 4 & 8 \\
\hline Animal & 4 & 6 & 2 & 12 & 11 & 3 & - & 14 \\
\hline Servant & 1 & 3 & 2 & 6 & 2 & - & 1 & 3 \\
\hline Journey & 1 & - & 1 & 2 & 5 & - & - & 5 \\
\hline Motion & 5 & 1 & 4 & 10 & 4 & 2 & 2 & 8 \\
\hline Machine & - & 2 & 1 & 3 & 1 & 4 & 2 & 7 \\
\hline Money & 8 & 4 & 1 & 13 & - & 3 & 1 & 4 \\
\hline Holding & - & - & - & - & 2 & - & 3 & 5 \\
\hline Seeing & 2 & 3 & 1 & 6 & - & 1 & - & 1 \\
\hline $\begin{array}{l}\text { physical } \\
\text { suffering }\end{array}$ & - & 2 & 1 & 3 & 1 & - & - & 1 \\
\hline Guide & 2 & - & 2 & 4 & 1 & - & - & 1 \\
\hline Other & 2 & 1 & 2 & 5 & - & 2 & - & 2 \\
\hline $\begin{array}{l}\text { Grand } \\
\text { Total }\end{array}$ & 177 & 171 & 196 & 544 & 231 & 220 & 181 & 632 \\
\hline
\end{tabular}

As table 2 shows, the two candidates mention the different categories of conceptual metaphors (1176) times: (544) times by Clinton 


\section{Wael Mohamed Kotb Khedr}

(46.2\%) and (632) times by Trump (53.8\%). The highest number of conceptual metaphor use is in the first debate (34.6\%), while the smallest number is in the third debate (32\%). Object metaphor is the most common category that the two candidates use $(30.4 \%)$. Having been mentioned only four times $(0.3 \%)$ by Clinton and Trump, physical suffering metaphors is the least used category. The two candidates utilize the spatial and person metaphors (191) times (16.2\%) and (220) times $(18.7 \%)$ respectively. Since these twenty different categories need hundreds of pages to be covered, the top five categories will be presented in the following pages.

\subsubsection{Object Metaphors}

In order to allow their audiences to conceptualize the ideas they are presenting, the two candidates excessively utilize the object metaphors in the three presidential debates. As clearly shown in table 2, both Clinton and Trump refer to this category of conceptual metaphors (160) times and (198) times respectively. "JOBS ARE OBJECTS", "NATIONS ARE OBJECTS", "PEOPLE ARE OBJECTS", AND "REGULATIONS ARE OBJECTS" are some of the dominant object metaphors that the two candidates utilize in the three presidential debates, as clearly shown in the following illustrative examples:

1-"I think building the middle class, investing in the middle class, making college debt-free, so more young people can get their education" (Clinton, first debate).

2-"I will bring -- excuse me. I will bring back jobs. You cannot bring back jobs"

(Trump, first debate).

The object metaphor "EDUCATION IS AN OBJECT" is quite noticeable in example 1. As a result of utilizing this metaphor, Clinton believes that college education can be handy and free for anyone provided that the government supports the middle class. In order to show how easy it is for him to bring back the jobs that fled outside the country, Trump uses the object metaphor "JOBS ARE OBJECTS" in example 2. $\mathrm{He}$ demonstrates his great commitment to carry out the necessary economic reforms.

\subsubsection{Person Metaphors}

Person metaphors are the second most frequently used conceptual metaphors in the 2016 presidential debates. Both candidates utilize these person metaphors (220) times: (101) times by Clinton and (119) times by Trump. Through the use of person metaphors, both Clinton and Trump 
are able to present their ideas in a clear and understandable way. They succeed in depicting the problems their country face and offer the solutions in a convincing way. "A COUNTRY IS A PERSON", "MILITARY IS A PERSON", "COMPANIES ARE PERSONS" AND "ISIS IS A PERSON" are some of significant person metaphors in the three presidential debates, as shown in the following examples:

3-“Our military is assisting in Iraq" (Clinton, first debate).

4-"So Ford is leaving. You see that, their small car division leaving. Thousands of jobs are leaving Michigan, leaving Ohio" (Trump, first debate).

"MILITARY IS A PERSON" is the person metaphor that Clinton makes use of in example 3 . Clinton presents the image of the military as a good person that supports and helps the Iraqi people. To show how the country is not supporting some famous companies like Ford, Trump uses the two person metaphors "a company is a person" and "JOBS ARE PERSONS" in example 4. He depicts the suffering of these companies as a person who decides to leave his home for a better life. He is trying to manipulate his audiences by arousing their emotions and feelings.

\subsubsection{Spatial Metaphors}

Orientational or spatial metaphors have to do with space. We can clearly notice from table 2 that the three debates contain (191) examples of spatial metaphors, making it the third highest category after object and person metaphors. "MORE IS UP”, "LESS IS DOWN", "FUTURE IS AHEAD", AND "HONOR IS UP" are some of the spatial metaphors that the two candidates use, as shown in the following examples:

5- "I hope by the time I am president that we will have pushed ISIS out of Iraq" (Clinton, second debate).

6-"He never apologized to Mr. and Mrs. Khan, the Gold Star family whose son, Captain Khan, died in the line of duty in Iraq" (Clinton, second debate).

7-“No, you're the puppet" (Trump, third debate).

Clinton employs the spatial metaphor "FUTURE IS AHEAD" in example 5 to shape an image in the minds of her audiences that she will win the elections. Criticizing Trump for insulting one of the American heroes who died for the cause in Iraq, Clinton utilizes the spatial metaphor "DUTY IS AN ORDERLY SPATIAL ARRANGEMENT" in example 6. To evoke the image of the unreliable person, Trump employs the spatial metaphor "BEING UNDER CONTROL IS DOWN" in example 7 . He wants to tell his audiences that Clinton will be unable to lead the country if she becomes the president. 


\section{Wael Mohamed Kotb Khedr}

\subsubsection{Competition Metaphors}

It is easy for audiences and readers to consider politics when it comes in the form of competitive sports (Gibbs, 2015). The two candidates see their running for presidency as a game or competition. Competition metaphors are present (94) times in the three debates. "PRESIDENTIAL ELECTIONS ARE A COMPETITION" and "POLITICIANS ARE WARRIORS" are the dominant competition metaphors in the debates under analysis, as the following examples show: 8- "So I have a comprehensive energy policy, but it really does include fighting climate change" (Clinton, second debate).

9-"But she does fight hard, and she does not quit" (Trump, second debate).

To warn her audiences about the negative consequences of rapid climate change, Clinton makes use of the competition metaphor "CLIMATE CHANGE IS A WAR" in example 8. Trump uses the competition metaphor "CLINTON IS A WARRIOR" in example 9 to show how strong Clinton is.

\subsubsection{Building Metaphors}

Another important category of conceptual metaphors that is helpful for the two candidates to present their ideas in an understandable way is the building metaphors. There are (53) examples of this category of metaphors. Clinton presents building metaphors (24) times, while Trump mentions them (29) times. "A NATION IS A BUILDING", "ECONOMY IS A BUILDING", "LIFE IS A BUILDING", AND "SOCIAL CLASS IS A BUILDING" are among the important building metaphors used in the debates under study. The following are some examples of the building metaphors:

10-“Their lives have been destroyed for doing one-fifth of what you've done" (Trump, second debate).

11-"We've got to get back to rebuilding the middle class, the families of America" (Clinton, third debate).

When talking about the deleted 33,000 e-mails, Trump uses the building metaphor "LIFE IS A BUILDING" in example 10 to tell his audiences about the sufferings of the citizens as a result of the information disclosure and what she has done. Stressing the fact that middle class is the essential element in the American society, Clinton uses the building metaphor "SOCIAL CLASS IS A BUILDING" in example 11 . 


\subsubsection{Force Metaphors}

Force metaphors are the category of conceptual metaphors that the two candidates exploit to create negative metaphoric references to some of the ideas and topics they are presenting. There are (49) instances of force metaphors in the debates under consideration. "DIFFICULTIES ARE OPPOSING FORCES", "REGULATIONS ARE A DESTRUCTIVE FORCE", and "A TRADE DEAL IS A DISASTER" some of the dominant force metaphors in the three presidential debates. 12-"Your regulations are a disaster" (Trump, first debate). 13-"There are children suffering in this catastrophic war, largely, I believe, because of Russian aggression" (Clinton, second debate). 14-"And one thing we have to do: Repeal and replace the disaster known as Obamacare" (Trump, third debate).

Examples 12-14 contain the following force metaphors: "REGULATIONS ARE A DESTRUCTIVE FORCE" (12), "WAR IS A DESTRUCTIVE FORCE" (13), and "OBAMACARE IS A DESTRUCTIVE FORCE" (14). The two presidential candidates employ the words "catastrophic" and "disaster" to arouse fear on the part of their audiences. These words are usually associated with natural disasters, like hurricanes and tornadoes that the country witnesses from time to time. After presenting the image of destruction, the two candidates start showing themselves as the savors who are going to rectify all the mistakes and solve all the problems. This is a good technique of using manipulation.

\subsubsection{Plant Metaphors}

Another important category of conceptual metaphors that plays a good role in simplifying the ideas and issues presented by the two candidates is the plant metaphors. They help the audiences to conceptualize the different ideas in a natural way. The total tally of the plant metaphors in the three debates is 33. "A NATION IS A PLANT" and "ECONOMY IS A PLANT" are the two dominant plant metaphors in the debates under scrutiny. The following examples illustrate some of these plant metaphors:

15-"We're going to grow the economy. It's going to grow at a record rate of growth" (Trump, third debate).

16- "Well, I think when the middle class thrives, America thrives" (Clinton, third debate).

"ECONOMY IS A PLANT" is the plant metaphor employed by Trump in example 15. He arouses his audiences' emotions by seeking their cooperation to recover the economy. Clinton utilizes the plant metaphor "A NATION IS A PLANT" in example 16 to give her 


\section{Wael Mohamed Kotb Khedr}

audiences a clear image of how developing the middle class casts a shadow on supporting the economy.

\subsubsection{Container and Liquid Metaphors}

Existing together in the majority of examples; container and liquid metaphors are present together in this section of the study. The presidential candidates employ container and liquid metaphors (53) times and (10) times respectively.

17-“People are pouring into our country" (Trump, first debate). 18-"And the Affordable Care Act was meant to try to fill the gap between people who were too poor" (Clinton, second debate).

In example 17, we can clearly see the container metaphor "A COUNTRY IS A CONTAINER" and the liquid metaphor "IMMIGRANTS ARE UNCONTROLLED FLOW OF WATER". Trump thinks that immigrants represent an immediate threat to the development of the country. "A GAP IS A CONTAINER" is the container metaphor that Clinton utilizes in example 18 to clarify the importance of the Affordable Care Act for the poor.

\subsubsection{Animal Metaphors}

In order to create an image of fear in the hearts of their audiences regarding certain issues, the two presidential candidates use some animal metaphors. Clinton, on the one hand, pays attention to 12 examples of animal metaphor. Trump, on the other hand, introduces 14 examples. "PEOPLE ARE ANIMALS" and "IMMIGRANTS ARE ANIMALS" are the dominant animal metaphors in the debates under analysis.

19-"But I want to emphasize that what is at stake here is the ambitions and the aggressiveness of Russia" (Clinton, second debate). 20-"We have gangs roaming the street" (Trump, first debate).

"A COUNTRY IS AN ANIMAL" is the animal metaphor employed by Clinton in example 19. Clinton sees Russia as a wild animal that tries to dominate the world. To represent the country as a jungle rather than an inhabitant area, Trump utilizes the animal metaphor "IMMIGRANTS ARE ANIMALS" in example 20.

\subsubsection{Servant Metaphors}

Servant metaphors are the category of conceptual metaphors that Clinton and Trump use to manipulate their audiences through arousing their emotions and feelings. While Trump uses three examples of servant metaphors, Clinton doubled the number (6 times). "A POLITICIAN IS A SERVANT" is the dominant metaphor in the three debates, as the following examples show: 
21-"And I can pledge to you tonight that this is the America that I will serve if I'm so fortunate enough to become your president" (Clinton, first debate).

22-“And I think I did a great job and a great service" (Trump, first debate).

23- "Let me talk about my 30 years in public service" (Clinton, second debate).

Considering themselves loyal servants of their country, Clinton and Trump employ the servant metaphor "A POLITICIAN IS A SERVANT" in examples 21-23. They see politics as a way of serving people. Clinton, on the one hand, is proud of being in public service for more than 30 years. Trump, on the other hand, is happy for supporting the economy through his massive construction projects. Expressing the image of being a servant helps in arousing emotions on the part of the audiences, which is, in turn, a good manipulative technique.

\subsubsection{Journey and Motion Metaphors}

Journey and motion metaphors are other two important categories of conceptual metaphors that help the audiences to understand abstract ideas in an easy way. While there are 7 instances of the journey metaphors in the debates under analysis, 18 examples of motion metaphors are clearly apparent. "LIFE IS A JOURNEY" and "CHANGE IS MOTION" are the important themes of both journey and motion metaphors in the three debates. The following are some examples of these two categories of conceptual metaphors:

24-"No wonder you've been fighting ISIS your entire adult life" (Trump, first debate).

25-"You should meet with some of the women that I have met with, women I have known over the course of my life" (Clinton, third debate).

In examples 24 and 25, the journey metaphors "LIFE IS A JOURNEY" is quite noticeable. Trump criticizes Clinton for telling ISIS about her plans to get rid of its fighters and supporters (example 24). Clinton praises the time she has spent in serving the country (example 25).

\subsubsection{Machine Metaphors}

Due to their strong effect on the audiences, machine metaphors are another category of conceptual metaphors employed by the two candidates in the debates under analysis. Clinton and Trump mention machine metaphors (3) times and (7) times respectively. "SOLVING PROBLEMS IS FIXING A MACHINE" is the predominant machine metaphors in the three presidential debates 


\section{Wael Mohamed Kotb Khedr}

26-"So let's fix what's broken about it, but let's not throw it away and give it all back to the insurance companies and the drug companies" (Clinton, second debate).

27-"But I want to do things that have not been done, including fixing and making our inner cities better for the African-American citizens that are so great" (Trump, second debate).

Examples 26 and 27 contain the machine metaphor "SOLVING PROBLEMS IS FIXING MACHINES". Clinton, on the one hand, invites her audiences to participate in both the decision-making process and the growth of the nation. Trump, on the other hand, sees himself as a repairman who could solve all the problems that his opponent has failed to fix when she was in power.

\subsubsection{Money Metaphors}

Money metaphors are another category of conceptual metaphors that is easy for readers and listeners to understand. Although Donald Trump is a businessman, he does not pay much attention to money metaphors. He employs only four money metaphor, while his opponent, Hillary Clinton, utilizes 13. "TIME IS MONEY "is the dominant money metaphor in the three debates.

28-"I've spent 30 years, actually maybe a little more, working to help kids and families" (Clinton, second metaphor).

29-"We use people that get the position because they gave -- they made a campaign contribution and they're dealing with China and people that are very much smarter than they are" (Trump, third debate).

Talking about her 30 years in public service, Clinton uses the money metaphor "TIME IS MONEY" in example 28. She wants to tell her audiences that as people spend their money having fun, she has spent her life serving her county. In example 29, Trump utilizes the money metaphor "NEGOTIATING WITH CHINA IS BUSINESS". Trump praises American businesspeople, describing them as the best negotiators in the world.

\subsubsection{Holding and Seeing Metaphors}

Holding and seeing metaphors give the readers and listeners the chance to conceptualize and understand mental images. While Clinton never uses any example of holding metaphors, her opponent uses five examples. The two candidates utilize seeing metaphors (7) times: (6) times by Hillary Clinton, and only one time by Donald Trump. While "BELIEVING IS SEEING" is the main theme of seeing metaphors, "POSSESSION IS HOLDING" is the significant topic of holding metaphors. The following are some example of these two categories of conceptual metaphors: 
30-"We just have a different view about what's best for growing the economy, how we make investments that will actually produce jobs and rising incomes" (Clinton, first debate).

31- "I built an unbelievable company. Some of the greatest assets anywhere in the world, real estate assets anywhere in the world, beyond the United States" (Trump, first debate).

Comparing her ideas to Trump's in terms of growing the economy, Clinton uses the seeing metaphor "HAVING A PLAN IS SEEING" in example 30. In example 31, Trump uses the holding metaphor "POSSESSION IS HOLDING" to praise his business. He sends a message to his audiences telling them that as he has been a successful businessman, he would also be a dependable and trusted president.

\subsubsection{Physical Suffering Metaphors}

Physical suffering metaphors give Hillary Clinton and Donald Trump the chance to depict the problems facing their countries as diseases and wounds that need immediate treatment. While Clinton mentions three instances of physical suffering metaphors, Trump employs only one example. The following are some of the physical suffering metaphors mentioned in the debates under study:

32-"I want us to heal our country and bring it together" (Clinton, second debate).

33-"When you talk about healing, I think that I've developed very, very good relationships over the last little while with the African-American community" (Trump, first debate).

In order to stir their audiences' emotions, Clinton and Trump employ the physical suffering metaphor "SOCIAL DIVISION IS A WOUND" in examples 32 and 33. They declare that their country is torn and in an urgent need of unity. Both of them believe that the only solution for this disturbing problem is to reject all the different forms of racism.

\subsubsection{Guide Metaphors}

Having been used once by Trump and four times by Clinton, guide metaphor is another category of conceptual metaphor that is important in making ideas clearer for audiences. The following are some examples of guide metaphors found in the debates under consideration:

34-"The plan he has will cost us jobs and possibly lead to another Great Recession" (Clinton, third debate).

35-"The deal with Iran will lead to nuclear problems" (Trump, first debate).

Criticizing Trump's plan which will, according her beliefs, destroy the economy, Clinton uses the guide metaphor "PLAN IS A GUIDE TOWARDS ILL-BEING" in example 34. She wants to inform her 


\section{Wael Mohamed Kotb Khedr}

audiences that once elected president, Trump would make the country suffer badly again. In example 35, Trump utilizes the guide metaphor "A DEAL IS A GUIDE TO DESTRUCTION". He attacks Clinton for making the Iranian deal that will threaten not only the United States, but also the whole world.

\subsubsection{Other Metaphors}

There are seven metaphors that do not belong to any of the abovementioned categories. For this reason, they are introduced in this separate section of the study. Clinton employs five of them, whereas Trump utilizes the other two. "BEING THE BEST IS BEING FIRST" is one metaphor that is employed three times by the two presidential candidates. The other four metaphors are "DEATH IS LOSS", "PEOPLE ARE WEIGHT", "PROBLEMS ARE SLAUGHTERS", and "BUSINESS IS A SHIP". The following examples show some of these metaphors:

36-"Do the thousands of people that you have stiffed over the course of your business not deserve some kind of apology" (Clinton, first debate). 37-"But we're going to do it in a way that tries to save some of these 33,000 lives that we lose every year" (Clinton, third debate).

Asking Trump to apologize to some workers who did some work for him without being properly paid or not being paid at all, Clinton employs the metaphor "BUSINESS IS A SHIP" in example 36. She sees Trump's business as a ship that sails from place to another without respecting laws or people's dignity. "DEATH IS LOSS" is the metaphor that Clinton mentions in example 37 when discussing the disastrous consequences of bearing guns.

As a result of skillfully using the different categories of metaphors, the two candidates are able to manipulate their audiences. They are also able to arouse their emotions and feelings. Some of these metaphors contribute in building their images as politicians.

In addition to manipulating lexico-semantically through the use of conceptual metaphors, presidential candidates can achieve manipulation by making use of the different forms of equivocations.

\subsection{Equivocations}

Equivocation is the second lexico-semantic manipulative device that politicians tend to employ to avoid the negative and unwanted consequences of answering directly (Clementson, 2016). Bavelas et al.'s (1990) presented a taxonomy that divides equivocation into four categories: sender, receiver, content, and context. Both Hillary Clinton and Donald Trump employ these four categories of equivocation in their attempt to avoid the undesirable consequences if they give clear and 
direct answers. The following table shows the tallies of the four categories of equivocation in the debates under analysis:

Table3.Occurrences of Equivocations

\begin{tabular}{|c|c|c|c|c|c|c|c|c|}
\hline \multirow[b]{2}{*}{$\begin{array}{l}\text { Element of } \\
\text { equivocation }\end{array}$} & \multicolumn{3}{|c|}{ Hillary Clinton } & \multirow[b]{2}{*}{ Total } & \multicolumn{3}{|c|}{ Donald Trump } & \multirow[b]{2}{*}{ Total } \\
\hline & $\begin{array}{l}1^{\text {st }} \\
\text { Debate }\end{array}$ & \begin{tabular}{|l|}
$2^{\text {nd }}$ \\
Debate \\
\end{tabular} & $\begin{array}{l}3^{\text {rd }} \\
\text { Debate }\end{array}$ & & $\begin{array}{l}1^{\text {st }} \\
\text { Debate }\end{array}$ & $\begin{array}{l}2^{\text {nd }} \\
\text { Debate }\end{array}$ & $\begin{array}{l}3^{\text {rd }} \\
\text { Debate }\end{array}$ & \\
\hline Sender & 29 & 14 & 23 & 66 & 26 & 21 & 21 & 68 \\
\hline Context & 5 & 4 & 6 & 15 & 12 & 9 & 9 & 30 \\
\hline Receiver & 9 & 3 & 5 & 17 & 23 & 8 & 6 & 37 \\
\hline Content & 1 & - & 1 & 2 & 7 & 3 & 3 & 13 \\
\hline Grand Total & 44 & 21 & 35 & 100 & 68 & 41 & 39 & 148 \\
\hline
\end{tabular}

As table 3 shows, the two candidates utilize the four categories of equivocation (348) times: (100) times $(40.3 \%)$ by Hillary Clinton and (148) times $(59.7 \%)$ by Donald Trump. The first debate has the highest number of equivocations (45.1\%), because the two candidates want to establish a solid ground before their audiences from the beginning. The second debate has the lowest number of equivocations (25\%). Of the four categories of equivocation, sender is the most used category (54\%), while content is the least used (6\%).

\subsubsection{Sender}

The two candidates employ many strategies to achieve equivocation on the part of the sender. They use others' opinions as well as some economic and governmental reports to avoid their responsibility over things. In order to manipulate their audiences, Clinton and Trump pay attention to some statistics and numbers that are not based on accurate and/ or reliable sources. Such statistic and numbers are in fact untrue. Their aim is both to attract their audiences' attention and attack their opponents. They also resort to using the inclusive pronoun "we" and the passive constructions. Clinton and Trump employ equivocation on the part of the sender (66) times and (68) respectively. In his answer to a question about supporting the war in Iraq, Trump provides the following answer:

38- "I had numerous conversations with Sean Hannity at Fox. And Sean Hannity said -- and he called me the other day -- and I spoke to him about it -- he said "you were totally against the war", because he was for the war" ( Trump, first debate).

In example 38, Trump utilizes another person's statement in order to persuade the moderator and the audiences that he was against the war in Iraq. By referring to what Sean Hannity has said, Trump wishes to refute the unsubstantiated allegation made by Clinton regarding his supporting the Iraqi war. When comparing the skillful and quiet 


\section{Wael Mohamed Kotb Khedr}

diplomacy that she had adopted when she was Secretary of States to Trump's diplomacy, Clinton refers to what Donald Trump had said. She states:

39- "The other day, I saw Donald saying that there were some Iranian sailors on a ship in the waters off of Iran, and they were taunting American sailors who were on a nearby ship. He said, "You know, if they taunted our sailors, I would blow them out of the water and start another war." That's not good judgment" (Clinton, first debate).

In example 39, Clinton quotes what Trump has said to show her audiences how irresponsible Trump will be if he wins the elections. She desires to persuade her audiences that Trump would start many wars in the world as a result of his policies.

\subsubsection{Context}

There two candidates employ some techniques to achieve equivocation on the part of context. In some situations, they give no answers to some questions at all. In other occasions, the two candidates are found responding to a part of the question and neglecting the other part(s). While Clinton employs equivocation on the part of the context (15) times, Trump doubled the number.

When asked if he would accept the outcomes of the presidential elections, Trump does not answer the question to the extent that the moderator repeats the question twice. His stunning refusal to answer the question cast doubts on the legitimacy of the elections in case Clinton wins. He talks about the corrupt media and its role in poisoning, as he claims, the minds of voters, as clearly obvious in example 40.

40- "I will look at it at the time. I'm not looking at anything now. I'll look at it at the time. What I've seen -- what I've seen is so bad. First of all, the media is so dishonest and so corrupt, and the pile-on is so amazing. The New York Times actually wrote an article about it, but they do not even care. It's so dishonest. And they've poisoned the mind of the voters... What I'm saying is that I will tell you at the time. I'll keep you in suspense (Trump, third debate).

\subsubsection{Receiver}

Receiver is the third category in Bavelas et al.'s equivocation taxonomy. Receiver concerns itself to answer the question "is the answer addressed to the immediate listener?" (Bavelas et al., 1990). The two 2016 presidential candidates use this equivocation category (54) times: (17) times by Clinton and (37) times by Trump.

In many occasions, the two candidates shift from addressing the moderators or people who ask questions (only in the second debate) to 
address each other with the aim of attacking, as the following examples clarify:

41- "If your main claim to be president of the United States is your business, then I think we should talk about that. You know, your campaign manager said that you built a lot of businesses on the backs of little guys. And, indeed, I have met a lot of the people who were stiffed by you and your businesses, Donald. I've met dishwashers, painters, architects, glass installers, marble installers, drapery installers, like my dad was, who you refused to pay when they finished the work that you asked them to do" (Clinton, first debate).

42- "She was a United States senator. She complains that Donald Trump took advantage of the tax code. Well, why did not she change it? Why did not you change it when you were a senator? The reason you did not is that all your friends take the same advantage that I do. And I do. You have provisions in the tax code that, frankly, we could change. But you would not change it, because all of these people gave you the money so you can take negative ads on Donald Trump" (Trump, second debate).

In her response to Trump's accusation of being responsible for the \$20 trillion debt (example 41), Clinton, instead of addressing the moderator, talked to Trump and attacked him and his businesses. Her aim is to avoid talking about the $\$ 6$ trillion spent in the Middle East. When the moderator asks Trump how to make sure the wealthy pay their taxes, Trump attacks Clinton for not changing the tax code when she was a senator (example 42). He even accused her of corruption. In the previous two examples, both Clinton and Trump mention the pronoun "you" instead of "he" and "she".

\subsubsection{Content}

Content is the last category of Bavelas et al.'s equivocation taxonomy. This category has to do with the clarity of the message being delivered (Bavelas et al., 1990). If the message is vague and ambiguous, this means the speaker is eager to equivocate. Of the four categories of Bavelas et al.'s equivocation taxonomy, content is the least used category. While Trump employs it (13) Times, Clinton uses it only twice, as the following examples show:

43- "And, you know, look, I understand that Donald's been strongly supported by the NRA" (Clinton, third debate).

44-"We are in a big, fat, ugly bubble. And we better be awfully careful. And we have a Fed that's doing political things. This Janet Yellen of the Fed. The Fed is doing political - by keeping the interest rates at this level" (Trump, first debate). 


\section{Wael Mohamed Kotb Khedr}

In example 43, Clinton mentions the acronym NRA without telling what it stands for. The meaning is not clear for many audiences. Clinton should have told the audiences what this acronym means, as she does in many other situations. The reason behind not telling its meaning maybe she thinks the audiences can guess the meaning from the context, or maybe she has no time. The message that Trump is delivering in example 44 is not clear. It is unknown why he mentions the name Janet Yellen.

\subsection{Emotive Language}

Taking into account the profound effect of emotive language, the two 2016 presidential candidates employ this great device to win the trust of their audiences and influence their decision. The two candidates' use of emotive language is meant to change the audiences' attitude towards actions. Being made use of when there is no evidence, emotive language is a tool utilized by the two candidates to manipulate their audiences. Emotive language presented in this study includes some nouns, verbs, adjectives, inclusive pronouns, adverbs, and some conceptual metaphors. The aforementioned linguistic factors play an important role in arousing the emotions and feelings of the audiences, and therefore, achieving the two candidates' goal of attaining manipulation. The following table shows the distribution of the emotive language in the three presidential debates under analysis:

Table13.Emotive Language Distribution

\begin{tabular}{|l|l|l|l|l|}
\hline & First debate & Second debate & Third debate & Total \\
\hline Hillary Clinton & 359 & 329 & 351 & $\mathbf{1 0 3 9}$ \\
\hline Donald Trump & 522 & 424 & 478 & $\mathbf{1 4 2 4}$ \\
\hline Grand Total & $\mathbf{8 8 1}$ & $\mathbf{7 5 3}$ & $\mathbf{8 2 9}$ & $\mathbf{2 4 6 3}$ \\
\hline
\end{tabular}

As table 13 shows, the two candidates make use of the emotive language (2463) times: (1039) times by Clinton (42.1\%) and (1424) times (57.9\%) by Trump. The highest number of the emotionally loaded words is in the first debate $(35.7 \%)$. The reason behind using such great number is the desire of the two candidates to attract the attention of their audiences from the beginning. The lowest number of emotive language is noticeably in the second debate $(30.5 \%)$.

Emotive language is expressed in some parts of speech such as nouns, pronouns, adjectives, adverbs, and verbs. Emotive language also 
finds its way in some auxiliary verbs like "should". The role played by metaphors in stirring the emotions and feelings of audiences is undeniable. It is worth noting that emotive language is closely connected with the inclusive pronouns "we', "us", and "our".

The following examples illustrate how Clinton and Trump present emotive language:

45-"I want to make America great again. We are a nation that is seriously troubled. We're losing our jobs. People are pouring into our country" (Trump, first debate).

46-"Everyone should be respected by the law and everyone should respect the law" (Clinton, first debate).

47-"First of all, Captain Khan is an American hero, and if I were president at that time, he would be alive today, because unlike her, who voted for the war without knowing what she was doing, I would not have had our people in Iraq. Iraq was disaster" (Trump, second debate).

48- "And I think when you look at the letters that I get; a lot of people are worried that maybe they would not have a place in Donald Trump's America" (Clinton, second debate).

In example 45, Trump arouses the emotions of his audiences many times through the use of a metaphor and some other words. He provokes the emotion of pride in his audiences when mentioning the adjective "great". He emphasizes the greatness of their country in all fields. To enhance the emotion of fear, he uses the inclusive pronouns "we" and "our" to express the significant problems facing their country. The emotion of fear is quite noticeable when he employs the container and liquid metaphor when stating "people are pouring into our country". Trump wants to tell his audiences that the immigrants will share all the privileges Americans receive. When talking about the use of force by the police in example 46, Clinton arouses the emotion of respect by using the modal verb "should". Clinton sees that the only way to restore trust between the police and the communities is respecting and applying laws.

In example 47, Trump succeeds in stirring the emotions of fear and sadness in his audiences as a result of mentioning the word "disaster". $\mathrm{He}$ blames and attacks Clinton for voting and supporting the war in Iraq. $\mathrm{He}$ tries to achieve manipulation by mentioning his opponent's previous actions. Using the adjective "worried" in example 48, Clinton arouses the emotion of fear in her audiences. She attacks her opponent's plans and policies, claiming citizens will suffer enormously as a result of these plans. She is in fact shaping a negative image of her opponent before the audiences. 


\section{Wael Mohamed Kotb Khedr}

\section{0-Conclusion}

To manipulate their audiences lexico-semantically, the two candidates use three different devices: conceptual metaphors, equivocations, and emotive language. The three types of conceptual metaphors (structural, orientational, and ontological) are present in many categories such as person, object, plant, animal, building, holding, etc... The two candidates' aim behind using conceptual metaphors is to let their audience understand the complex ideas in simple and illustrative ways. To avoid the demanding and undesirable consequences of answering directly, the two candidates employ the four categories of Bavelas et al.'s equivocation taxonomy known as sender, receiver, context, and content. The third lexico-semantic manipulative device is the use of the emotionally loaded words or emotive language, which can be achieved through the use of many syntactic and semantic elements such as nouns, pronouns, verbs, adjectives, and metaphors.

The study was able to answer the research questions. As for the question "What are the different verbal lexico-semantic manipulative devices used by the presidential candidates in the debates under consideration?", the study concluded that there are three lexico-semantic manipulative devices that are greatly paid much attention to by the two candidates. These devices are conceptual metaphors, equivocation techniques, and emotive language.

In its answer to the question "What are the most and least frequently used lexico-semantic manipulative devices?", the study concluded that lexico-semantic manipulative devices are used (3887) times: (1683) times (43.2\%) by Hillary Clinton, and (2204) times (56.8\%) by Trump. With a total number of (2463) times, emotive language is the most dominant used device. The different categories of conceptual metaphors come in the second place, with a total number of (1176) occurrences. Being used only (248) times, equivocations are the least used device. Of the twenty different categories of conceptual metaphors, object metaphors are the most used category (30.4\%).

As for the question "How is verbal manipulation considered as an important factor in winning the presidential debates?", the study indicated that it is clear that manipulation works better in arousing and evoking the emotions and feelings of audiences. Manipulation is also beneficial when there is a lack of evidence or no evidence at all. One of the outcomes that the two candidates' manipulative linguistic practices accomplish is confusion. They distract and deflect from facts in a clear effort to sidestep truths that conflict with their narrative about various issues. 


\section{References}

Arfiani, F.R. (2017). The Use of Metaphors in Hillary Clinton's Presidential Debate [Batchelor's thesis, Mataram University]. The Information Resources

Center. http://eprints.unram.ac.id/11814/1/jurnal\%20THE\%20USE\%20OF\%20META PHORS\%20IN\%20HILLARY\%20CLINTON\%27S\%20PRESIDENTIAL\%20 DEBATES pdf.

Asya, A. (2013). Linguistic manipulation: Definition and types. International Journal of Cognitive Research in Science, Engineering and Education.Vol.1, No.2. Retrieved 25 November, 2014, from http://www.ijcrsee.com. ijcrsee article view.pdf.

Bavelas, J.B., Black, A., Bryson, L., \& Mullett, J. (1988). Political equivocation: A situational explanation. Journal of Language and Social Psychology, 7, 137-145.

Bavelas, J. B., Black, A., Chovil, N., \& Mullett, J. (1990). Equivocal communication. Newbury Park, CA: Sage.

Bull, P. (2003). The microanalysis of political communication. London, England: Routledge.

Bull, P. (2008). Slipperiness, evasion, and ambiguity: Equivocation and facework in noncommittal political discourse. Journal of language and social psychology, 27(4), 333-344.

Bull, P. (2012). Adversarial discourse in prime minister's questions. Journal of language and social psychology, 31(1), 30-48.

Bull, P, \& Mayer, K. (1993). How not to answer questions in political interviews. Political Psychology, 4 , 651-666.

Clementson, D. E. (2016). Why do we think politicians are so evasive? Insight from theories of equivocation and deception, with a content analysis of U.S. presidential debates, 1996-2012. Journal of Language and Social Psychology, 35(3), 247-267. https://doi.org/10.1177/0261927X15600732

Curbelo, A. (2017). Analyzing the (Ab)use of language in politics: The case of Donald Trump. Retrieved May15, 2019 from https://www.bristol.ac.uk/medialibrary/sites/spais/documents/Working\%20Paper\%2002_17_AAC. pdf

Duffy, M. (2018). Detention of terrorism suspects: Political discourse and fragmented practices. United Kingdom: Bloomsbury Publishing.

Feldman, O., Kinoshita, K., \& Bull, P. (2015). Culture or communicative conflict? The analysis of equivocation in broadcast Japanese 


\section{Wael Mohamed Kotb Khedr}

political interviews. Journal of Language and Social Psychology, $34,65-89$.

Gibbs, R.W. (2015). The allegorical character of political metaphors in discourse. Metaphor and the Social World 5 (2): 264-282.

Haley, J. (1959). An interactional description of schizophrenia.
Psychiatry,
22(4),
321-332.

https://doi.org/10.1080/00332747.1959.11023187

Kazemifard, M., Ghasem-Aghaee, N., \& Ören, T. I. (2012). Emotive and cognitive simulations by agents: Roles of three levels of information processing. Cognitive Systems Research, 13(1), p. 2438.

Knowles, M \& Moon, R. (2006). Introducing Metaphor. London: Routledge

Kovecses, Z. (2005). Metaphor and culture: Universality and variation. New York: Cambridge University Press.

Lakoff, G. (2001). Moral politics. Chicago: University of Chicago Press.

Lakoff, G. \& Johnson, M. (1980). Metaphors we live by. Chicago: Chicago University Press.

Lakoff, G., \& Johnson, M. (2003). Metaphors we live by. London: University of Chicago Press. http://dx.doi.org/10.7208/chicago/9780226470993.001.0001

Lewin, K. (1939). Field theory and experiment in social psychology: Concepts and methods. American Journal of Sociology, 44(6), 868896. https://doi.org/10.1086/218177

Mieder, W. (2010). Making a way Out of no way: Martin Luther King's sermonic proverbial rhetoric. Austria: Peter Lang.

Musolff, A. (2019). Language aggression in public debates on immigration. Netherlands: John Benjamins Publishing Company.

Ottati, V, C. \& Renstrom, A, R. (2010). Metaphor and persuasive communication: A multifunctional approach. Social and Personality Psychology Compass 4 (9): 783-794.

Palacios, L. (2018). The 2016 U.S. presidential debates: A discourse analysis approach. Retrieved June 13, 2019 from https://rodin.uca.es/xmlui/bitstream/handle/10498/20674/Luc\%C3 \%ADaRamos_TFG_EEII_FINAL.pdf?sequence $=1$ \&isAllowed $=\mathrm{y}$

Sartika, E. (2017). Language function used by Hillary Clinton in the presidential debates of United States of America in 2016. International Pragmatics, 25(2), 168-189.

Smith, G. (2019). Cattle, progress, and a victimized nation: Exploring metaphors in current and past immigration discourse. Metaphor and the Social World, 9, 263-284. 
Smithson, R. (2013). Rhetoric and psychopathy: Linguistic manipulation and deceit in the final interview of Ted Bundy. Journal of Undergraduate Research Volume 6 (2) 1-13.

Sperber, D. \& Wilson, D. (1986). Relevance: Communication and cognition. Oxford: Oxford University Press.

Sperber, D. \& Wilson, D. (2008). A deflationary account on metaphors. In Gibbs, R.W. (Ed). The Cambridge Handbook of Metaphor and Thoughts. New York: CUP, p.84-108.

The Nielsen Company. (2008). Highest rated presidential debates 1960 to present. Retrieved June 26, 2020, from https://www.nielsen.com/us/en/insights/article/2008/top-tenpresidential-debates-1960-to-present/

Vrij, A. (2008). Detecting lies and deceit: Pitfalls and opportunities. Chichester: John Wiley.

Wallace, J. M., Irwin, W., Bassham, G., Nardone, H. (2012). Critical Thinking: A Student's Introduction. United Kingdom: McGraw-Hill Education.

\section{Dictionary Entities}

Equivocation. (2015). Dictionary.com. Retrieved from https://www.dictionary.com/browse/equivocation

Metaphor.(2016). Merriam Webster. Retrieved from https://www.merriam-webster.com/dictionary/metaphor 